\title{
DNA Barcoding and CITES-Listed Wedgefish (Rhynchobatidae, Rhinidae) from South Bangka, Indonesia
}

\author{
Siti Aisyah ${ }^{*}$, Novi Santia ${ }^{1}$, Okto Supratman' ${ }^{1}$ Ahmad Fahrul Syarif2, Anggraeni3 \\ 'Aquatic Resource Management Department, Faculty of Agriculture Fisheries and Biology, \\ University of Bangka Belitung \\ ${ }^{2}$ Aquaculture Department, Faculty of Agriculture Fisheries and Biology, University of Bangka Belitung \\ 3Biology Department, Faculty of Agriculture Fisheries and Biology, University of Bangka Belitung \\ JI. Kampus Terpadu UBB, Balunijuk, Kab. Bangka, Kepulauan Bangka Belitung 33172 Indonesia \\ Email: sitiaisyahsa057@gmail.com
}

\begin{abstract}
Overfishing of wedgefish greatly affects its population and the balance of the marine ecosystem. This is exacerbated by their relatively low fecundity, slow growth, and late maturity results in one of the lowest population growth rate within elasmobranch species. However, lacking database information results in insufficient regulations and surveillance of wedgefish fishing. The current situation is feared to the risk of wedgefish's survival, especially in Bangka Belitung Islands, Indonesia. Fundamental to a database is the accurate identification of wedgefish species based on mitochondrial DNA (mtDNA) analysis. This study aimed to use DNA barcodes to identify, determine the conservation status, and the status according to the Convention on International Trade in Endangered Species of Wild Fauna and Flora (CITES). We collected samples including unidentified fin samples from confiscated illegal fishing catches, the traditional markets and fishing docks, South Bangka. In this research, we used DNA Barcoding (mitocondrial DNA, COI gene) to identify and examine of wedgefish samples. The tissue samples used in this study were identified as species listed in CITES Appendix II, they are Rhynchobatus australiae, Rhynchobatus springeri and Rhina ancylostoma. According to the IUCN Red List, $100 \%$ of the wedgefish species found are Critical Endangered at the global level.
\end{abstract}

Keywords: DNA Barcoding, Wedgefish, endangered species, South Bangka

\section{INTRODUCTION}

A major problem in estimating catch rates of sharks and rays is the potential for misidentification. Some shark and ray species are difficult to distinguish morphologically and there are ethnic differences in understanding or interpreting common names (Burgess et al., 2005). The Food and Agriculture Organization (FAO) report described the paucity of good fishery data for elasmobranchs (Castro et al., 1999). The valuable shark fins in South-east Asia has led to an increase in illegal, unreported, and unregulated (IUU) shark and ray fishing. Overfishing of wedgefish, a group of rays also known as Rhynchobatidae in the family Rhinidae, greatly affects its population and the balance of the marine ecosystem. Their relatively low fecundity, slow growth, long lifespan, and late maturity resulted as one of the lowest population growth rate among elasmobranch species, making them more vulnerable for fishing pressure (Dulvy et al., 2014).

Currently, shark and ray populations in Indonesia are going to decline, especially wedgefish species. These fishes are oftenly found in South Bangka in Bangka Belitung Islands, Indonesia. According to the Ministry of Marine Affairs and Fisheries, Indonesia was the world's largest producer of sharks and rays, contributing $12.31 \%$ of the global total catch (Fahmi and Dharmadi, 2013). However, a lack of database information induces insufficient regulation and oversight of the management of wedgefish fishing. The current situation is be alarmed about the risk of wedgefish's survival 

survival of wedgefish, especially in Bangka Belitung Islands. Fundamental to a database is the accurate identification of wedgefish species. Samples from the South Bangka will contribute as a reference for determining the conservation and CITES statuses of wedgefish in the Bangka Belitung Island province.

Species were identified based on mitochondrial DNA (mtDNA) analyses. DNA barcoding is an established powerful tool for fish species identification (Ward et al., 2005; Ward et al., 2009), especially when the entire organism cannot be accessed for morphology. However, there are important limitations concerning its accuracy, which depend on the reference database available and the degree of genetic differentiation among species (Fernanda et al., 2018). This study aimed to use DNA barcodes to identify species of wedgefish from South Bangka, Bangka Belitung Islands, Indonesia, and to determine their conservation status and CITES-listing.

\section{MATERIALS AND METHOD}

Samples included unidentified fin samples from confiscated illegal fishing catches and were collected from the traditional markets and fishing docks, South Bangka. They were preserved in a solution of $90 \%$ alcohol or frozen at $-4{ }^{\circ} \mathrm{C}$ (depend on the size of samples).

We extracted genomic DNA from tissue samples around 0,03 to $0,05 \mathrm{~g}$ using ZR Tissue and Isect DNA MiniPrep (Zymo Research, D6016), following the manufacturer's protocol. DNA amplification was performed of the targeted locus Cytochrome Oxidase Subunit 1 (COI) gene with a Polymerase Chain Reaction (PCR) using the universal primers (Table 1). We used MyTaq Red Mix (Bioline) for amplification PCR with the following steps: 3 min denaturation at $96^{\circ} \mathrm{C}$, followed by 35 cycles of denaturation at $94^{\circ} \mathrm{C}$ for $10 \mathrm{~s}, 50{ }^{\circ} \mathrm{C}$ annealing for $30 \mathrm{~s}$, and $72{ }^{\circ} \mathrm{C}$ extention for $45 \mathrm{~s}$. We examined the PCR products on $1 \%$ agarose gel electrophoresis. The PCR products were sent to sequencing service for DNA sequencing.

Amplicons were sequenced in both forward and reverse directions. The sequencing results of the $\mathrm{COI}$ gene nucleotide character were compilating using MEGA $X$ software for trimming, reverse complement, and alignment processes (Tamura et al., 2013). The aligned results were then matched to the nucleotide database in GenBank on the National Center for Biotechnology Information (NCBI) website. Phylogenetic analysis is a taxonomic classification of organisms based on the sample's phylogeny and is an integral part of systematic science and has the aim of determining the phylogeny of organisms based on the sample's characteristics (Mouth, 2001). The evolutionary history was inferred using the Neighbor-Joining method (Saitou and Nei, 1987). Phylogenetic tree was tested with 1000 bootstrap (replicates) to obtain the bootstrap convidence level (Felsenstein, 1985). The tree is drawn to scale, with branch lengths in the same units as those of the evolutionary distances used to infer the phylogenetic tree. The evolutionary distances were computed using the Kimura 2parameter method (Kimura, 1980). The analysis allows us to identify close sequences occupying neighboring branches of the tree. When gene families are found in organisms or groups of organisms, phylogenetic relationships between them can predict the possibility of equivalent functions (Mcdonald and Kreitman, 1991; Nielsen and Yang, 1998).

\section{RESULT AND DISCUSSION}

We obtained COI barcode sequences for samples included unidentified dried fin samples with sequence lengths ranging around $700 \mathrm{bp}$. All samples were successfully

Table 1. Primer set in this study

\begin{tabular}{llc}
\hline \multicolumn{1}{c}{ Primer } & \multicolumn{1}{c}{ Sequence } & Reference \\
\hline VF2_tl & 5'TGTAAAACGACGGCCAGTCAACCAACCACAAAGACATTGGCAC3' & Ward et al. (2005) \\
FishF2_tl & 5' TGTAAAACGACGGCCAGTCGACTAATCATAAAGATATCGGCAC3' & Ward et al. (2005) \\
FishR2_t1 & 5'CAGGAAACAGCTATGACACTTCAGGGTGACCGAAGAATCAGAA3' & Ward et al. (2005) \\
FR1d_tl & 5'CAGGAAACAGCTATGACACCTCAGGGTGTCCGAARAATCARAA3' & Ivanova et al. (2007) \\
\hline
\end{tabular}


amplified, most barcodes produced clear matches in BLAST allowing for confident assignment of species with $>99 \%$ similarity to database records. These three species had a match with NCBI BLAST sequences, they are Rhynchobatus australiae (Whitley, 1939), Rhynchobatus springeri (Compagno and Last, 2010), Rhina ancylostoma (Bloch and Schneider, 1801).

The tissue samples used in this study were identified as species listed in CITES Appendix II, they have been approved for listing on CITES Appendix II in the 18th CoP meeting in Geneva in August 2019. According to the IUCN Red List, $100 \%$ of the wedgefish species found are Critical Endangered at the global level (Kyne, 2019).

The phylogenetic study of wedgefish in this study was based on a 700 bp sequence of the $\mathrm{COI}$ gene. Results from phylogenetic analysis revealed a monophyletic clade for $R$. ancylostoma supported by a $100 \%$ bootstrap value. $R$. springeri and $R$. australiae formed a distinct monophyletic clade from each other supported by a $100 \%$ and $98 \%$ bootstrap value. These findings, together with their closer genetic distance to each other, indicated that wedgefish shared the same common ancestor.

According to CITES Appendix ॥ regulations, any trade of listed shark or ray species requires proof that the nation of origin has methods in place that ensure that the proposed trade is sustainable and not detrimental to any wild populations. Given that sharks and rays are typically characterized by low fecundity, late maturity, and a long gestation period, the finding that $71 \%$ of all sampled fins and gill plates came from species of high-conservational concern suggests that this segment of the global fisheries is anything but sustainable and urgently requires an extensive conservation management response (Steinke et al., 2017).

The DNA analysis of our samples indicates $R$. springeri, $R$. australiae and $R$. ancylostoma species are being traded directly exported to other areas. The large amount of samples belonging to this species suggests that they are neither by-catch nor

Table 2. Similarity of species in GenBank

\begin{tabular}{llcc}
\hline Sample Code & Species & \% Query Cover & \% Per Ident \\
\hline MBS_1 & Rhynchobatus australiae & $93 \%$ & $99.70 \%$ \\
MBS_2 & Rhynchobatus australiae & $94 \%$ & $99.85 \%$ \\
MBS_3 & Rhynchobatus springeri & $99 \%$ & $99.41 \%$ \\
MBS_4 & Rhina ancylostoma & $94 \%$ & $100 \%$ \\
\hline
\end{tabular}
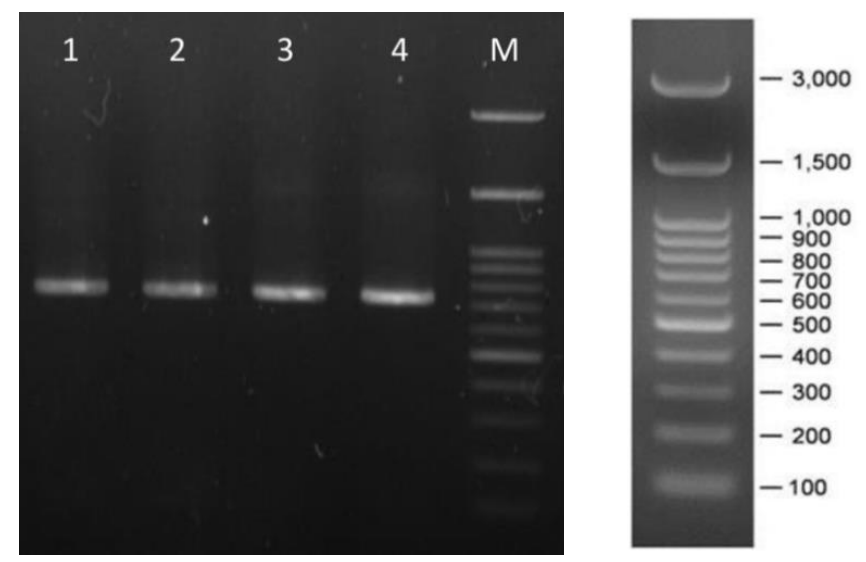

Figure 1. Electrophoresis gel patterns of PCR products shown at sequence lengths between $\sim 700 \mathrm{bp}$ (1= sample code MBS_1; $2=$ sample code MBS_2; 3 = sample code MBS_3; 4 = sample code MBS_4; $M=$ Marker) 


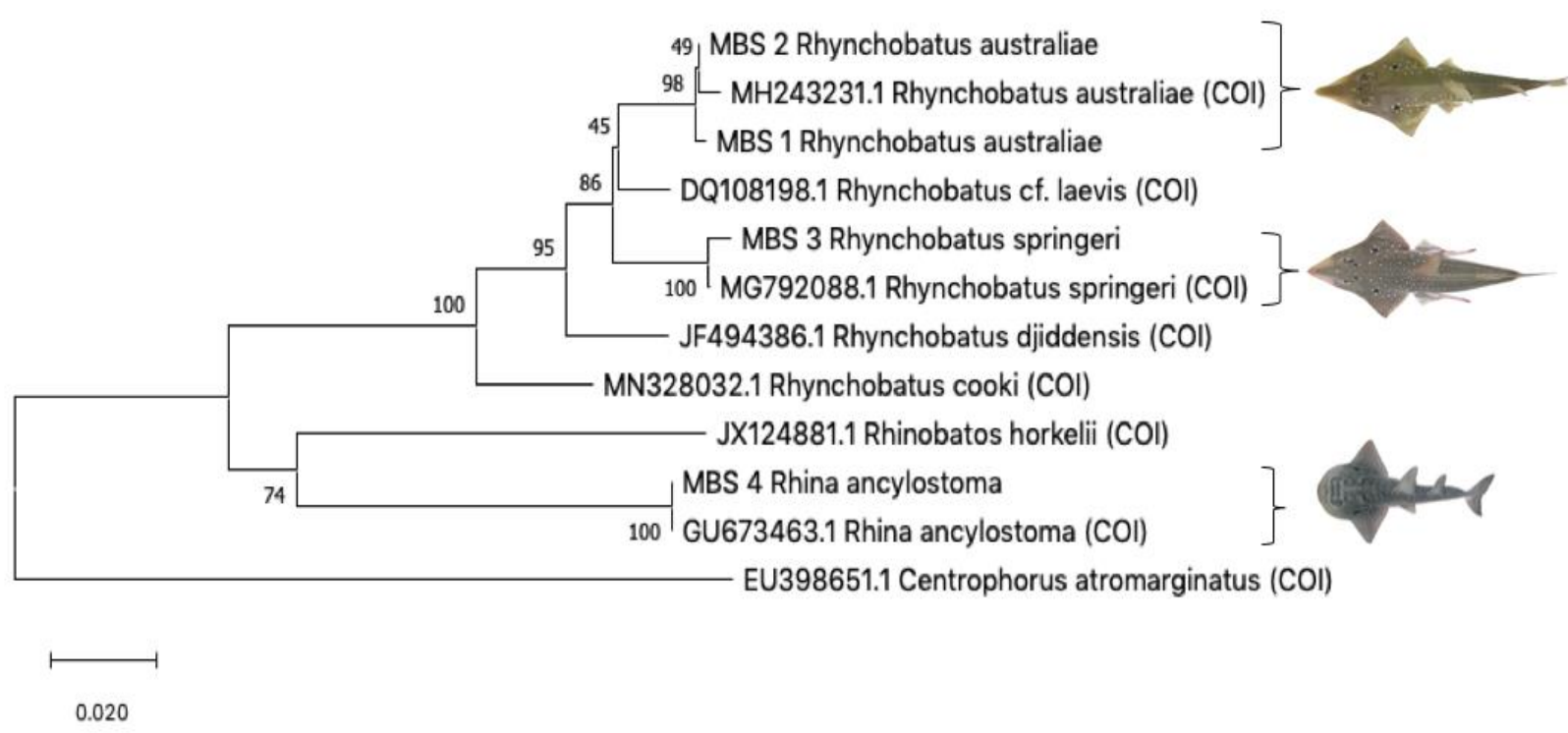

Figure 2. The phylogenetic tree of Cytochrome Oxidase Subunit 1 (COI) gene

imported from small-scale fisheries, but are instead harvested through large-scale fisheries, as has also been documented by other barcoding studies with a focus on shark and ray products (Dent \& Clarke, 2015). Our study confirmed that DNA identification of samples using mitochondrial $\mathrm{CO}$ barcoding sequencing can act as a powerful market surveillance tool. While shark and ray conservation and management policies are primarily focused on the development of fisheries quotas and marine protected areas, this work demonstrated the importance of market surveillance as a conservation countermeasure that would benefit from large-scale long-term monitoring. The results also raise further concerns about the impacts of trade on the sustainability of these low reproductive species demanding swift and extensive conservation management responses.

\section{CONCLUSION}

DNA identification of meat samples and dried ray fins using mitochondrial $\mathrm{COI}$ linked them to $R$. springeri, $R$. australiae and $R$. ancylostoma species with a similarity of $>99 \%$ with the NCBI sequence. The wedgefish species have been approved for listing on CITES Appendix II in the 18th CoP meeting in Geneva in August 2019. They are also listed in the IUCN Red List categorized as Critically Endangered. Based on exploration in local market and ask to fishermen, the wedgefish species are being traded directly exported to other areas, we urge increased transparency of the trade in this species for monitoring the sustainability and extensive conservation management responses.

\section{ACKNOWLEDGMENT}

The authors would like to thank the Ministry of Research and Technology for providing research funds, Aquatic Resource Management - University of Bangka Belitung, and to all those who kindly helped us to support this research.

\section{REFERENCES}

Burgess, G.H., Beerkircher, L.R., Cailliet, G.M., Carlson, J.K., Cortés, E., Goldman, K.J., Grubbs, R.D., Musick, J.A., Musyl, M.K., \& Simpfendorfer, C.A. 2005. Is the collapse of shark populations in the Northwest Atlantic Ocean and Gulf of Mexico real? . Fisheries, 30:19-26. doi: 10.1577/1548-84 46(2005)30[19:ITCOSP]2.0.CO;2

Castro, J.I., Woodley, C.M. \& Brudeck, R.L. 1999. A preliminary evaluation of the status of shark species. Fisheries Technical Paper No.380. Food and Agriculture 
Organization of the United Nations, Rome. $72 \mathrm{pp}$.

Compagno, L.J.V., \& Last, P.R. 2010. A new species of Rhynchobatus springeri (Rhynchobatoidei, In: Last, P.R., White, W.T., Pogonoski, J.J. (eds) Descriptions of new sharks and rays from Borneo. CSIRO Marine and Atmospheric Research Paper, Australia. 165 pp.

Fahmi \& Dharmadi. 2013. Tinjauan status perikanan hiu dan upaya konservasinya di Indonesia. Direktorat Konservasi Kawasan dan Jenis Ikan, Direktorat Jenderal Kelautan, Pesisir, dan PulauPulau Kecil, Kementerian Kelautan dan Perikanan, Indonesia. 168 pp.

Dent, F., \& Clarke, S. 2015. State of the global market for shark products. Food and Agriculture Organization of the United Nations, Rome. 187 pp.

Dulvy, N.K., Pardo, S.A., Simpfendorfer, C.A., \& Carlson, J.K. 2014. Diagnosing the dangerous demography of manta rays using life history theory. PeerJ 2:e400. doi: $10.7717 /$ peerj. 400

Felsenstein, J. 1985. Confidence limits on phylogenies: An approach using the bootstrap. Evolution, 39:783-791.

Fernanda, A., Sperb, C., Castilho, C.L., Figueiredo, P.I.C.C., Gonçalves, L.T., Machado, R., Oliveira, L.R., Valiati, V.H., \& Fagundes, N.J.R. 2018. Molecular identification of shark meat from local markets in Southern Brazil based on DNA barcoding: Evidence for mislabeling and trade of endangered species. Frontiers in Genetics, 9:138 pp. doi: 10.3389/fgene. 2018.00138

Ivanova, N.V., Zemlak, T.S., Hanner, R.H., \& Hebert, P.D. 2007. Universal Primer cocktails for fish DNA barcoding. Molecular Ecology Notes, 7(4):544-548.
Kimura, M. 1980. A simple method for estimating evolutionary rate of base substitutions through comparative studies of nucleotide sequences. Journal of Molecular Evolution, 16:111-120.

Kyne, P.M. 2019. Rhynchobatus springeri. The IUCN Red List of Threatened Species 2019: e.T60182A124448942. doi: 10.2305/ IUCN.UK.2019-2.RLTS.T60182A124448942. en

Mcdonald, J.H., \& Kreitman, M. 1991. Adaptive protein evolution at the Adh locus in Drosophila. Nature, 351:652-654. doi: 10. 1038/351652a0

Nielsen, R., Yang, Z. 1998. Likehood models for detecting positively selected amino acid sites and application to the HIV-1 envelope gene. Genetics, 148: 929-936.

Saitou, N. \& Nei, M. 1987. The neighbor-joining method: A new method for reconstructing phylogenetic trees. Molecular Biology and Evolution, 4:406-425.

Steinke, D., Bernard, A.M., Horn, R.L., Hilton, P., Hanner, R., \& Shivji, M.S. 2017. DNA Analysis of traded shark fins and mobulid gill plates reveals a high proportion of species of conservation concern. Scientific reports, 7:9505.

Tamura, K., Stecher, G., Peterson, D., Filipski, A., \& Kumar, S. 2013. MEGA 6: Molecular evolutionary genetics analysis version 6.0. [Computer software]. Molecular Biology and Evolution, 30:2725-2729. doi: 10.1093 /molbey/mst197

Ward, R. D., Zemlak, T. S., Innes, B. H., Last, P. R., \& Hebert, P.D.N. 2005. DNA barcoding Australia's fish species. Philosophical transactions of the royal society of London. Series B Biological Sciences, 360: 1847-1857. doi: 10.1098/rstb.2005.1716

Ward, R. D., Hanner, R., \& Hebert, P.D.N. 2009. The campaign to DNA barcode all fishes, FISH-BOL. Journal of Fish Biology, 74:329356. doi: $10.1111 /$ j.1095-8649.2008.02080.x 